\section{Benzyladenine and Gibberellins Improve Postharvest Quality of Cut Asiatic and Oriental Lilies}

\author{
Susan S. Han \\ Department of Plant and Soil Sciences, French Hall, University of \\ Massachusetts, Amherst, MA 01003 \\ Additional index words. Lilium sp., foliar chlorosis, growth regulator, bud blasting, vase life
}

Abstract. The effects of the duration of cold storage, as well as the concentration, timing, and means of application of a solution containing $25 \mathrm{mg} \cdot \mathrm{L}^{-1}$ each of benzyladenine (BA) and gibberellins $\left(\mathbf{G A}_{4+7}\right)$ on the postharvest quality of cut Asiatic and Oriental lilies (Lilium sp.) were evaluated. Depending on the cultivar, lower leaves began to turn yellow between 1 and 2 weeks after placing non-cold-stored stems in $20^{\circ} \mathrm{C}$ room illuminated $12 \mathrm{~h} \cdot \mathrm{d}^{-1}$ with $8 \mu \mathrm{mol} \cdot \mathrm{m}^{-2} \cdot \mathrm{s}^{-1}$ from cool-white fluorescent lamps. Leaf yellowing continued to progress upward until the end of the vase life. Cold storage $\left(3.3^{\circ} \mathrm{C}\right)$ worsened the leaf disorder, particularly, on the Oriental lily 'Stargazer'. The longer the duration of cold storage, the earlier the development of leaf yellowing and the higher the percentage of leaves that were chlorotic. In addition, cold storage induced bud blasting, inhibited flowers from fully opening, and reduced the longevity and fresh weight of open flowers and the vase life of cut stems. Spraying leaves with a solution containing $25 \mathrm{mg} \cdot \mathrm{L}^{-1}$ each of $B A$ and $\mathbf{G A}_{4+7}$ significantly reduced cold-storage-induced leaf yellowing, bud blasting, and vase life of three of the four cultivars tested. The development of leaf yellowing declined with increasing concentration of $\mathbf{B A}+\mathbf{G A}_{4+7}$. The susceptibility of 'Stargazer' to cold-storage-induced leaf yellowing and bud blasting can be counteracted by a concentration of growth regulators higher than that which was effective for the other cultivars. Timing of the $\mathbf{B A}+\mathbf{G A}_{4+7}$ application was not critical, as there were no differences in leaf yellowing or bud development when the solution was sprayed before or after the cold storage. Addition of $\mathbf{B A}+\mathbf{G A}_{4+7}(0.5$ or $2.5 \mathrm{mg} \cdot \mathrm{L}^{-1}$ of each) to the preservative solution or a pulsed treatment in solutions containing $25 \mathrm{mg} \cdot \mathrm{L}^{-1}$ each of $\mathrm{BA}$ and $\mathrm{GA}_{4+7}$ for 4 hours prevented leaf yellowing, but increased bud blasting. For practical applications, growth regulators can be sprayed prior to or after cold storage in order to improve the postharvest leaf and flower quality of cut lilies.

Asiatic and Oriental lilies have long been produced for use as cut flowers and have gained popularity in recent years. In the Netherlands, Lilium is the second to Tulipa among flower bulbs crop produced (van der MeulenMuisers, 1999). One of the major postproduction disorders is the development of leaf yellowing or browning, which usually starts on the lower leaves and moves progressively upward. In addition to other factors, cold storage may contribute to the development of leaf yellowing in lilies (Nell et al., 1998; Ranwala et al., 2000). However, when crops are grown for use as cut flowers, cold storage before marketing is inevitable, and, with the increase in global transportation of cut flowers, the duration and temperature of storage can vary greatly. In addition, symptoms of leaf disorders often are not evident when plants are

\footnotetext{
Received for publication 28 Apr. 2000. Accepted for publication 6 Sept. 2000. Publication no. 3278 of the Massachusetts Agricultural Experiment Station. I thank Montgomery Rose, Inc. in Hadley, Mass., for donation of the cut flowers, Agtrol Chemical in Houston, Texas, for donation of the growth regulators, and the New England Floriculture, for partially funding this project. The cost of publishing this paper was defrayed in part by the payment of page charges. Under postal regulations, this paper therefore must be hereby marked advertisement solely to indicate this fact.
}

removed from the cold room but can quickly develop in an interior environment, thus providing buyers little indication of the quality of cut stems.

Variation in the postproduction performance of different cultivars was well documented for potted lilies by Leonard et al. (1998). In that study, the symptoms and severity of the leaf disorders of 30 cultivars greatly varied. In a separate report, the same researchers reported that leaf disorders (leaf yellowing, browning, abscission, etc.) commonly occurred on potted plants that had been cold- stored for $4 \mathrm{~d}$ or longer, and thus recommended that marketable plants not be coldstored (Nell et al., 1998).

Lower leaf yellowing has always been the major postproduction problem for potted Easter lilies. Han (1995) first reported that a combination of gibberellins (GAs) and benzyladenine (BA) reduced yellowing in excised Easter lily leaves and later reported that one application of Promalin ${ }^{\circledR}$ (Abbott Laboratories, North Chicago), which contains both $\mathrm{GA}_{4+7}$ and BA, completely prevented postproduction leaf yellowing (Han, 1997). In Oriental lilies, cold-storage-induced leaf yellowing in potted 'Stargazer' was completely eliminated by spraying plants with Promalin ${ }^{\circledR}$ (100 $\mathrm{mg} \cdot \mathrm{L}^{-1}$ each of BA and $\mathrm{GA}_{4+7}$ ) prior to storage and by storing in an illuminated cooler
(Ranwala et al., 2000). In potted Asiatic lily, an application of $>250 \mathrm{mg} \cdot \mathrm{L}^{-1}$ each of BA and $\mathrm{GA}_{4+7}$ completely prevented leaf yellowing on plants that had been cold-stored for up to 3 weeks (Funnell and Heins, 1998). Thus studies suggest the potential use of $\mathrm{BA}+\mathrm{GA}_{4+7}$ on cut hybrid lilies where cold storage of the flowers is unavoidable.

To date, the use of $\mathrm{GA}_{4+7}$ and BA to prevent leaf yellowing or browning in cut hybrid lilies has not been investigated. The objectives of this study were to investigate the optimum concentration, timing, and means of application of $\mathrm{BA}+\mathrm{GA}_{4+7}$ for improving postharvest leaf and flower quality in cut lilies.

\section{Materials and Methods}

General procedures. Cut hybrid lilies were harvested from local commercial greenhouses when the largest flower bud on each stem was showing color, and were transported to a $20^{\circ} \mathrm{C}$ laboratory within an hour. Unless otherwise stated, leaves were then sprayed with either water or with a growth regulator solution containing $25 \mathrm{mg} \cdot \mathrm{L}^{-1}$ each of BA and $\mathrm{GA}_{4+7}$ and air-dried in the laboratory. Each stem was then maintained, for postharvest evaluation, in an individual $100-\mathrm{mL}$ tube containing a preservative solution of $2 \%$ sugar and $200 \mathrm{mg} \cdot \mathrm{L}^{-1}$ hydroxyquinoline citrate (HQC). Cold-stored stems were sleeved and stored dry in a $3.3^{\circ} \mathrm{C}$ dark cooler for 1 or 2 weeks. Postharvest quality of the stems was evaluated in a $20^{\circ} \mathrm{C}$ simulated interior environment illuminated $12 \mathrm{~h} \cdot \mathrm{d}^{-1}$ with $8 \mu \mathrm{mol} \cdot \mathrm{m}^{-2} \cdot \mathrm{s}^{-1}$ from cool-white fluorescent lamps. The development of leaf yellowing, longevity of each flower bud, percentage of blasted buds, and the vase life of each stem were monitored. Vase life was defined as the number of days from the end of the cold treatment to the day when the last flower bud on each stem senesced. Leaves were considered senescent when $>50 \%$ of the area had become chlorotic or necrotic. Eight replicate stems were used per treatment in each experiment.

Cold storage. Cut stems of two cultivars of Asiatic lily, 'Geneve' and 'Vivaldi', and of two cultivars of Oriental lily, 'Stargazer' and 'Acapulco', were evaluated. Unless otherwise stated, a factorial design, consisting of three durations of $3.3^{\circ} \mathrm{C}$ storage $(0,1$, or 2 weeks) and two treatments (water or BA $\left.+\mathrm{GA}_{4+7}\right)$, was used. In addition, fresh weights of fully opened flowers were recorded on a separate group of 'Stargazer' lilies being treated in the same way as those used in the postharvest evaluation.

Concentration. After harvest, leaves of 'Stargazer' were sprayed with 0 (control), 0.5 , $2.5,5$, or $25 \mathrm{mg} \cdot \mathrm{L}^{-1}$ each of BA and $\mathrm{GA}_{4+7}$. Stems were then cold-stored for 1 week prior to postharvest evaluation. In a separate study, leaves were sprayed with 0 (control), 25, 50, 125,250 , or $500 \mathrm{mg} \cdot \mathrm{L}^{-1}$ each of BA and $\mathrm{GA}_{4+7}$ and stems were cold-stored for 0 or 2 weeks.

Timing of application. Leaves on 'Stargazer' and 'Geneve' stems were sprayed with water (control) or with $25 \mathrm{mg} \cdot \mathrm{L}^{-1}$ each of BA and $\mathrm{GA}_{4+7}$ before or after a 2 -week cold storage. 
Method of application. Stems of 'Stargazer' were sprayed with water (control) or with $25 \mathrm{mg} \cdot \mathrm{L}^{-1}$ each of BA and $\mathrm{GA}_{4+7}$, pulsed in $25 \mathrm{mg} \cdot \mathrm{L}^{-1}$ each of $\mathrm{BA}$ and $\mathrm{GA}_{4+7}$ solution for $4 \mathrm{~h}$ before placing the stems in the preservative solution, or placed in 100-mL tubes containing the preservative solution plus 0 (control), 0.5 or $2.5 \mathrm{mg} \cdot \mathrm{L}^{-1}$ each of BA and $\mathrm{GA}_{4+7}$.

Statistical analysis. Data were analyzed with SAS's General Linear Model procedure (SAS Institute, 1992). Percentage data were arcsin transformed prior to analysis. Differences among treatments were further analyzed with either Duncan's multiple range test or paired comparisons.

\section{Results}

Cold storage and leaf quality. Without cold storage, leaves of cut Oriental lily 'Stargazer' and 'Acapulco' began to turn yellow on Day 9 and 12, respectively (Fig. 1). The percentage of chlorotic leaves increased rapidly 3 to 4 d later, resulting in $76 \%$ and $27 \%$ chlorotic leaves at the end of the vase life for 'Stargazer' and 'Acapulco', respectively (Table 1). Cold storage hastened the development of chlorotic leaves (Fig. 1) and significantly reduced the longevity of individual flowers and the vase life of cut stems (Table 1). Regardless of cultivar, leaves on stems cold-stored for 1 and 2 weeks began to turn yellow $\approx 4$ to $8 \mathrm{~d}$ earlier than those not cold-stored, and yellowing increased linearly until the last flower senesced. The final percentage of chlorotic leaves was $88 \%$ at Day 14 and $84 \%$ at Day 8 for 'Stargazer' stored for 1 and 2 weeks, respectively. The final leaf yellowing in 'Acapulco' was less severe, with $26 \%$ and $50 \%$ chlorotic leaves when the vase life ended at Day 15 and Day 12 for those cold-stored for 1 or 2 weeks.

Postharvest leaf yellowing also developed in cut Asiatic lily and was worsened by cold storage (Fig. 1). Without cold storage, leaf yellowing was first detected on both cultivars at Day 6. The percentage of chlorotic leaves continued to increase until the end of the vase life, with $39 \%$ and $28 \%$ of the leaves chlorotic at the end of the vase life for 'Geneve' and 'Vivaldi', respectively (Table 1). In 'Geneve', 2 weeks of $3.3{ }^{\circ} \mathrm{C}$ storage induced a greater amount of leaf yellowing than those not coldstored, but 1 week did not. 'Vivaldi' was slightly more susceptible to cold-storage-induced leaf yellowing than was 'Geneve', with significantly more chlorotic leaves after 1 week of cold storage.

In general, spraying leaves of Oriental and Asiatic lily with $25 \mathrm{mg} \cdot \mathrm{L}^{-1}$ each of BA and $\mathrm{GA}_{4+7}$ completely prevented postharvest leaf yellowing (Fig. 1).

Cold storage and flower performance. Longevity of open flowers was significantly reduced by $3.3^{\circ} \mathrm{C}$ storage, but not affected by the position of the buds on the stems. Data for all buds on each stem were therefore pooled. In Oriental lilies, 2 weeks at $3.3{ }^{\circ} \mathrm{C}$ significantly reduced flower longevity, increased bud blasting, and reduced the size (based on fresh weight) of the open flowers, the angle at which the petals reflex when fully opened

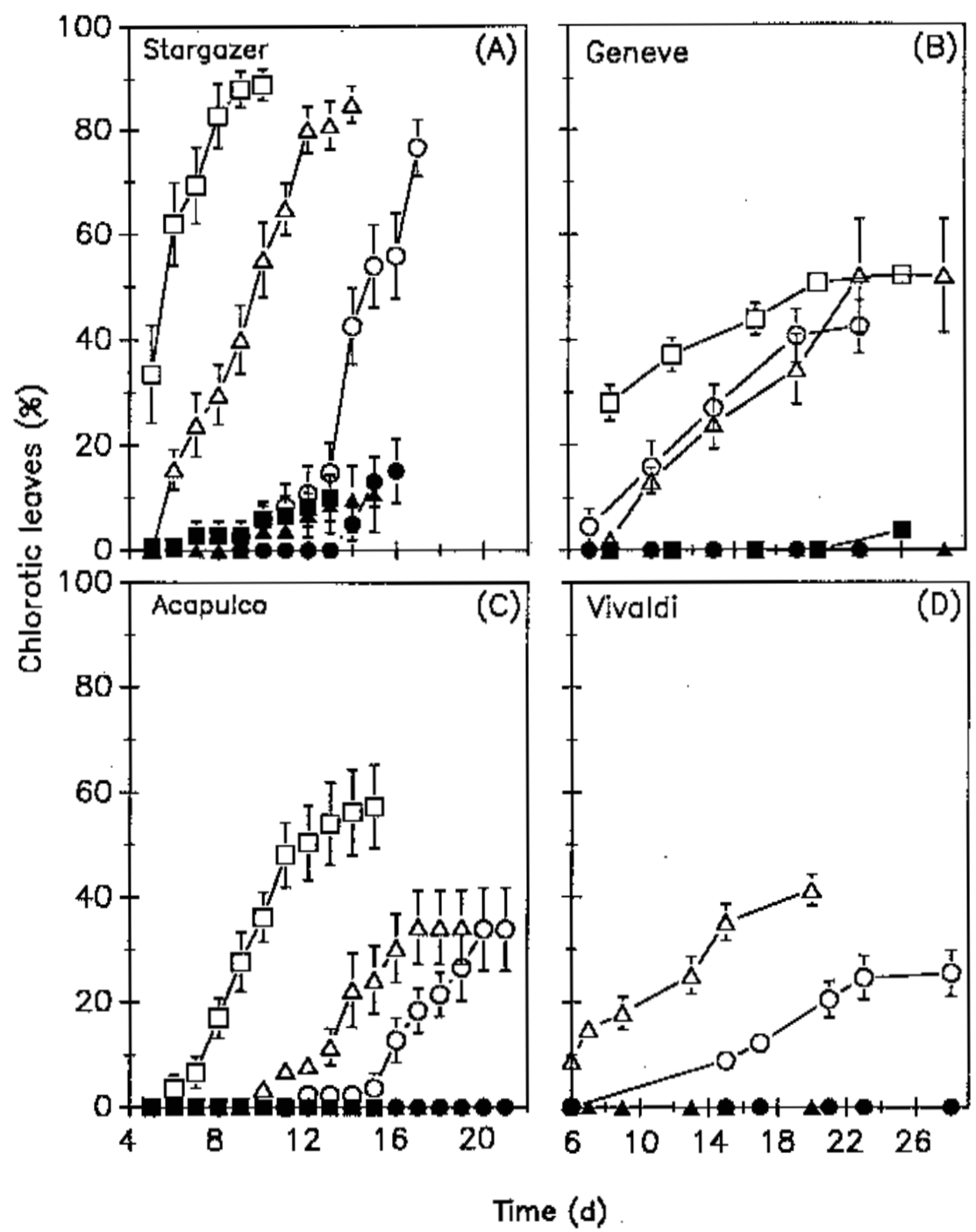

Fig. 1. Effects of cold storage and growth regulator treatment on the postharvest quality of cut stems of Oriental lilies (A, C) and two of Asiatic lilies $(\mathbf{B}, \mathbf{D})$. Leaves were sprayed with water (open symbols) or $25 \mathrm{mg} \cdot \mathrm{L}^{-1}$ each of $\mathrm{BA}$ and $\mathrm{GA}_{4+7}$ (solid symbols), allowed to air dry, and then sleeved and stored in a $3{ }^{\circ} \mathrm{C}$ cold room for $0(\bigcirc), 1(\Delta)$ or $2(\square)$ wks. Cut stems were then placed in a solution containing $2 \%$ sugar and $200 \mathrm{mg} \cdot \mathrm{L}^{-1}$ of hydroxyquinoline citrate. The development of leaf yellowing was evaluated in a $20^{\circ} \mathrm{C}$ interior environment illuminated $12 \mathrm{~h} \cdot \mathrm{d}^{-1}$ with $8 \mu \mathrm{mol} \cdot \mathrm{m}^{-2} \cdot \mathrm{s}^{-1}$ from a cool-white fluorescent lamp. Data are means \pm SE of eight replicate stems.

(data not shown), and the vase life of the cut stems (Table 1). In 'Stargazer', 33.3\% of the buds (all of the third buds on each stem) blasted after 2 weeks of storage at $3.3{ }^{\circ} \mathrm{C}$. Fresh weight of individual flowers decreased from the $14.7 \pm 0.7 \mathrm{~g}$ (controls) to $10.8 \pm 0.5 \mathrm{~g}$ on stems cold-stored for 2 weeks. The vase life of the stems decreased from $16.9 \mathrm{~d}$ to 13.9 and $8.5 \mathrm{~d}$ for 'Stargazer' cold stored for 0,1 , and 2 weeks, respectively (Table 1).

Bud blasting and reduction in size and longevity of flowers from the 2-week cold storage, however, was partly counteracted by $\mathrm{BA}+\mathrm{GA}_{4+7}$ application. Flowers on coldstored stems treated with growth regulators lasted as long as those that had not been coldstored, and the size of the open flowers (based on fresh weight) was significantly larger than those not treated. Nevertheless, the BA $+\mathrm{GA}_{4+7}$ treatment did not completely overcome the deleterious effects of cold storage. Vase life of the $\mathrm{BA}+\mathrm{GA}_{4+7}$-treated, cold-stored stems and the longevity of individual flowers was still significantly shorter than were those of stems that had not been cold-stored. Flowers on the growth regulator-treated, cold-stored stems weighed $12.6 \pm 0.4 \mathrm{~g}, \approx 2 \mathrm{~g}$ less than those on the non-cold-stored stems. The differences in size were visibly distinguishable.

Longevity of Asiatic lily flowers was also significantly reduced by storage at $3.3{ }^{\circ} \mathrm{C}$ (Table 1). However, unlike Oriental lilies, cold storage did not induce bud blasting, despite the higher bud count on each stem (five to six buds in Asiatic vs. three to four in Oriental lilies). Vase life of 'Geneve' was not affected by cold storage, whereas 1 week of storage at $3.3^{\circ} \mathrm{C}$ significantly reduced the vase life of 'Vivaldi'.

Growth regulator concentration. Concentrations $<2.5 \mathrm{mg} \cdot \mathrm{L}^{-1}$ each of $\mathrm{BA}$ and $\mathrm{GA}_{4+7}$ were ineffective in delaying leaf yellowing, whereas a concentration of $5 \mathrm{mg} \cdot \mathrm{L}^{-1}$ was partially effective (Fig. 2). The percentage of 
Table 1. Effects of cold storage and growth regulator treatment on the postharvest quality of two cultivars of cut Oriental lilies and two of Asiatic lilies. Leaves were sprayed with water or $25 \mathrm{mg} \cdot \mathrm{L}^{-1} \mathrm{each}$ of $\mathrm{BA}$ and $\mathrm{GA}_{4+7}$, allowed to air dry, and then sleeved and stored in a $3{ }^{\circ} \mathrm{C}$ cold room for 0 , 1 , or 2 weeks Cut stems were then placed in a solution containing $2 \%$ sugar and $200 \mathrm{mg} \cdot \mathrm{L}^{-1}$ of hydroxyquinoline citrate. Postharvest quality of the stems was evaluated in a $20^{\circ} \mathrm{C}$ interior environment illuminated 12 $\mathrm{h} \cdot \mathrm{d}^{-1}$ with $8 \mu \mathrm{mol} \cdot \mathrm{m}^{-2} \cdot \mathrm{s}^{-1}$ from a cool white fluorescent lamp. Data are means $\pm \mathrm{sE}$ for eight replicate stems.

\begin{tabular}{|c|c|c|c|c|c|}
\hline Cultivar & $\begin{array}{l}\text { Storage time } \\
\text { (wk) }\end{array}$ & Treatment & $\begin{array}{c}\text { Longevity } \\
\text { (days) }\end{array}$ & $\begin{array}{c}\text { Bud blasting } \\
(\%)\end{array}$ & $\begin{array}{c}\text { Vase life } \\
\text { (days) }\end{array}$ \\
\hline \multicolumn{6}{|c|}{ Oriental lilies } \\
\hline \multirow[t]{6}{*}{ Stargazer } & 0 & Water (control) & $6.0 \pm 0.3$ & 0 & $16.9 \pm 0.1$ \\
\hline & & $\mathrm{BA}+\mathrm{GA}_{4+7}$ & $6.6 \pm 0.3$ & 0 & $17.1 \pm 0.1$ \\
\hline & 1 & Water (control) & $5.7 \pm 0.3$ & $4.2 \pm 4.2$ & $13.9 \pm 0.6$ \\
\hline & & $\mathrm{BA}+\mathrm{GA}_{4+7}$ & $6.0 \pm 0.3$ & $8.3 \pm 5.4$ & $13.9 \pm 0.4$ \\
\hline & 2 & Water (control) & $4.4 \pm 0.1$ & $29.2 \pm 7.5$ & $8.4 \pm 0.5$ \\
\hline & & $\mathrm{BA}+\mathrm{GA}_{4+7}$ & $5.7 \pm 0.3$ & $7.3 \pm 4.8$ & $11.4 \pm 0.7$ \\
\hline \multirow[t]{7}{*}{ Acapulco } & 0 & Water (control) & $8.0 \pm 0.2$ & 0 & $18.8 \pm 0.6$ \\
\hline & & $\mathrm{BA}+\mathrm{GA}_{4+7}$ & $9.5 \pm 0.1$ & 0 & $20.1 \pm 0.2$ \\
\hline & 1 & Water (control) & $7.5 \pm 0.2$ & 0 & $14.6 \pm 0.4$ \\
\hline & & $\mathrm{BA}+\mathrm{GA}_{4+7}$ & $7.6 \pm 0.3$ & 0 & $15.5 \pm 0.8$ \\
\hline & 2 & Water (control) & $6.0 \pm 0.3$ & 0 & $11.8 \pm 1.1$ \\
\hline & & $\mathrm{BA}+\mathrm{GA}_{4+7}$ & $7.1 \pm 0.2$ & 0 & $15.4 \pm 0.6$ \\
\hline & & & & ANOVA & \\
\hline \multirow[t]{3}{*}{ Stargazer } & Storage (S) & & $* * *$ & $* * *$ & $* * *$ \\
\hline & Treatment (T) & & $* * *$ & $*$ & $* *$ \\
\hline & $\mathrm{S} \times \mathrm{T}$ & & NS & $*$ & $* *$ \\
\hline \multirow[t]{3}{*}{ Acapulco } & $\mathrm{S}$ & & $* * *$ & --- & $* * *$ \\
\hline & $\mathrm{T}$ & & $* * *$ & --- & $* * *$ \\
\hline & $\mathrm{S} \times \mathrm{T}$ & & $* * *$ & --- & NS \\
\hline & & Asiati & & & \\
\hline \multirow[t]{6}{*}{ Geneve } & 0 & Water (control) & $7.9 \pm 0.2$ & 0 & $17.4 \pm 0.7$ \\
\hline & & $\mathrm{BA}+\mathrm{GA}_{4+7}$ & $7.8 \pm 0.2$ & 0 & $17.2 \pm 0.2$ \\
\hline & 1 & Water (control) & $5.9 \pm 0.5$ & 0 & $17.4 \pm 0.7$ \\
\hline & & $\mathrm{BA}+\mathrm{GA}_{4+7}$ & $6.9 \pm 0.2$ & 0 & $19.0 \pm 0.8$ \\
\hline & 2 & Water (control) & $3.8 \pm 0.4$ & 0 & $15.6 \pm 1.0$ \\
\hline & & $\mathrm{BA}+\mathrm{GA}_{4+7}$ & $4.8 \pm 0.4$ & 0 & $15.2 \pm 0.9$ \\
\hline \multirow[t]{5}{*}{ Vivaldi } & 0 & Water (control) & $9.4 \pm 0.3$ & 0 & $22.9 \pm 1.0$ \\
\hline & & $\mathrm{BA}+\mathrm{GA}_{4+7}$ & $12.1 \pm 0.3$ & 0 & $23.8 \pm 0.9$ \\
\hline & 1 & Water (control) & $7.0 \pm 0.5$ & 0 & $19.4 \pm 0.2$ \\
\hline & & $\mathrm{BA}+\mathrm{GA}_{4+7}$ & $8.6 \pm 0.5$ & 0 & $18.6 \pm 0.5$ \\
\hline & & & & ANOVA & \\
\hline \multirow[t]{3}{*}{ Geneve } & Storage (S) & & $* * *$ & & $* *$ \\
\hline & Treatment (T) & & $*$ & & NS \\
\hline & $\mathrm{S} \times \mathrm{T}$ & & NS & & NS \\
\hline \multirow[t]{3}{*}{ Vivaldi } & $\mathrm{S}$ & & $* * *$ & & $* * *$ \\
\hline & $\mathrm{T}$ & & $*$ & & NS \\
\hline & $\mathrm{S} \times \mathrm{T}$ & & NS & & NS \\
\hline
\end{tabular}

, ${ }^{*},{ }^{* *}{ }^{* * *}$ Nonsignificant or significant at $P<0.05,0.01$, or 0.001 , respectively.

chlorotic leaves on plants sprayed with 25 $\mathrm{mg} \cdot \mathrm{L}^{-1}$ each of BA and $\mathrm{GA}_{4+7}$, however, was $10 \%$. Treatment with concentrations $>25$ $\mathrm{mg} \cdot \mathrm{L}^{-1}$ each of BA and $\mathrm{GA}_{4+7}$ did not further reduce leaf yellowing on non-cold-stored stems, but significantly delayed opening of the buds. However, when stems were coldstored for 2 weeks, treatment with concentrations $>50 \mathrm{mg} \cdot \mathrm{L}^{-1}$ each of $\mathrm{BA}$ and $\mathrm{GA}_{4+7}$ was more effective in delaying leaf yellowing than was $25 \mathrm{mg} \cdot \mathrm{L}^{-1}$ each of $\mathrm{BA}$ and $\mathrm{GA}_{4+7}$ (data not shown). In addition, treatment with $>50 \mathrm{mg} \cdot \mathrm{L}^{-1}$ each of $\mathrm{BA}$ and $\mathrm{GA}_{4+7}$ significantly reduced bud blasting and increased vase life of the stems (Fig. 3).

Timing of growth regulator application. In Oriental lily 'Stargazer' and in Asiatic lilies, the timing of the application did not affect leaf yellowing or the development of the flower buds when applied either before or after 1 or 2 weeks storage at $3{ }^{\circ} \mathrm{C}$ (data not shown).

Method of growth regulator application. Addition of 0.5 or $2.5 \mathrm{mg} \cdot \mathrm{L}^{-1}$ each of BA and $\mathrm{GA}_{4+7}$ into the vase solution completely pre- end of the vase life, but on cold-stored stems, leaves began to turn yellow 4 to $6 \mathrm{~d}$ after removal from the cooler, while the flowers were still developing, thus greatly reducing the quality of the stems. The development of leaf yellowing in cut 'Stargazer' was more severe and was earlier than that in potted lilies (Ranwala and Miller, 1998). In Asiatic lilies, leaf yellowing on stems cold-stored for 1 week resulted in 26 to 27 chlorotic leaves at Day 20 (Fig. 1). These leaf numbers are substantially higher than the 12 senesced leaves (Day 20) in potted Asiatic lily 'Donau' that were coldstored for $10 \mathrm{~d}$ (Funnell and Heins, 1998). The discrepancy might be due to cultivar differences or to an increase in susceptibility of lilies to leaf chlorosis when used as cut flowers.

The global transport of cut flowers requires storage at cool temperatures in order to sustain the quality of buds and flowers, but this practice may lead to an increase in leaf yellowing in lilies. Spraying leaves either before or after cold storage with a solution containing 25 $\mathrm{mg} \cdot \mathrm{L}^{-1}$ each of BA and $\mathrm{GA}_{4+7}$, however, counteracted the detrimental effects of cold storage. The flexibility in the timing of application indicates that treatments can be applied either by growers prior to shipping or by the retail florists after cold storage. In potted lilies, Ranwala and Miller (1998) also reported that spraying with $100 \mathrm{mg} \cdot \mathrm{L}^{-1}$ each of BA and $\mathrm{GA}_{4+7}$ before cold storage completely prevented leaf yellowing in 'Stargazer' and that a solution containing $10 \mathrm{mg} \cdot \mathrm{L}^{-1}$ each of BA and $\mathrm{GA}_{4+7}$ was only partially effective. In the experiments that we conducted, a growth regulator solution containing $25 \mathrm{mg} \cdot \mathrm{L}^{-1}$ each of BA and $\mathrm{GA}_{4+7}$ completely prevented leaf yellowing in most cases, whether or not the stems had been cold-stored. In some experiments, $10 \%$ to $20 \%$ of leaves on the treated 'Stargazer' turned yellow, which corresponds to an average of one to two yellow leaves on each stem, although there was some variation. Increasing the concentrations to $>50 \mathrm{mg} \cdot \mathrm{L}^{-1}$ each of BA and $\mathrm{GA}_{4+7}$ reduced the variability, as well as the percentage of leaf yellowing, as reported in potted Asiatic lily (Funnell and Heins, 1998). In their study, a solution containing 250 or 500 $\mathrm{mg} \cdot \mathrm{L}^{-1}$ each of $\mathrm{BA}$ and $\mathrm{GA}_{4+7}$ completely prevented leaf yellowing, whereas the number of senesced leaves per plant was highly variable at lower concentrations.

In addition to spraying, another method of applying growth regulators to cut stems is by addition to the vase solution. Treatment can be applied as a pulsed treatment (by treating stems for $<24 \mathrm{~h}$ ) or by the addition of chemicals to the preservative solution. In hybrid lilies, the addition of growth regulators to the preservative solution completely prevented leaf yellowing but induced bud blasting. Pulsing stems with concentrations of growth regulators lower than that used in this study or for a shorter period of time might prevent the negative effects of the growth regulators on the developing buds. In goldenrod (Solidago canadensis L.), pulsing cut stems in a BA solution for $19 \mathrm{~h}$ effectively delayed leaf yellowing (Philisoph-Hadas et al., 1996). Leaf yellowing in cut Alstromeria hybrida L. 


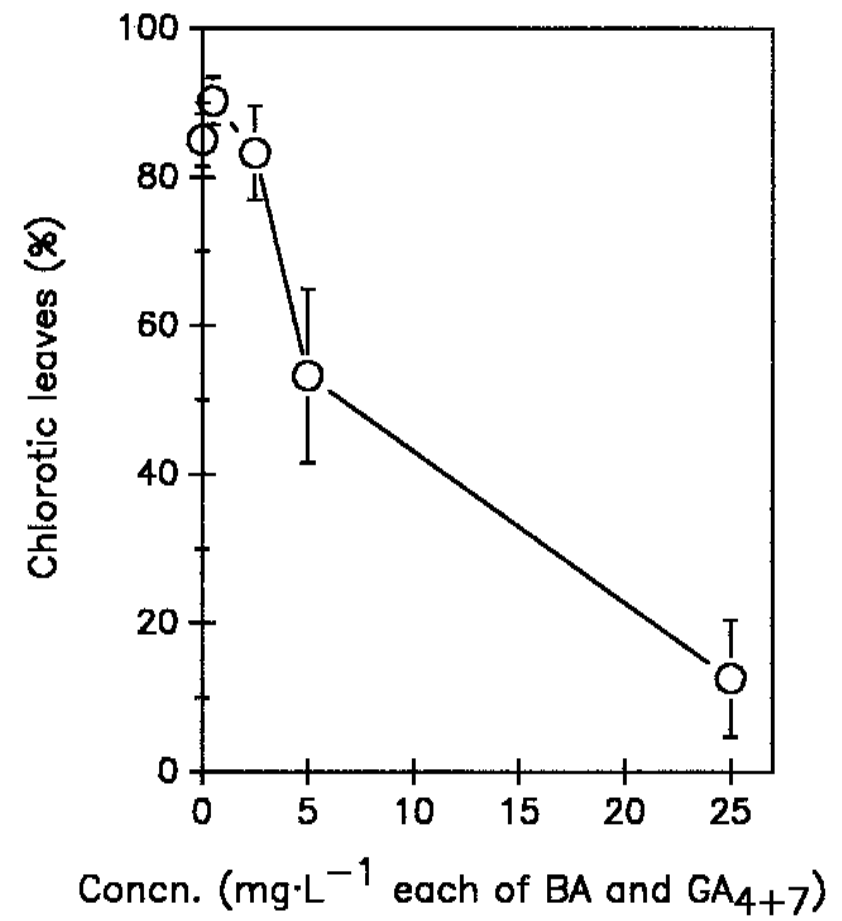

Fig. 2. Development of leaf yellowing in cut Oriental lily 'Stargazer' treated before cold storage with water (control) or various concentrations of $\mathrm{BA}$ and $\mathrm{GA}_{4+7}$. Leaves were sprayed, allowed to air dry, and then sleeved and stored in a $3{ }^{\circ} \mathrm{C}$ room for 1 week. Cut stems were then placed in a solution containing $2 \%$ sugar and $200 \mathrm{mg} \cdot \mathrm{L}^{-1}$ of hydroxyquinoline citrate. Data are means \pm SE of eight replicate stems.
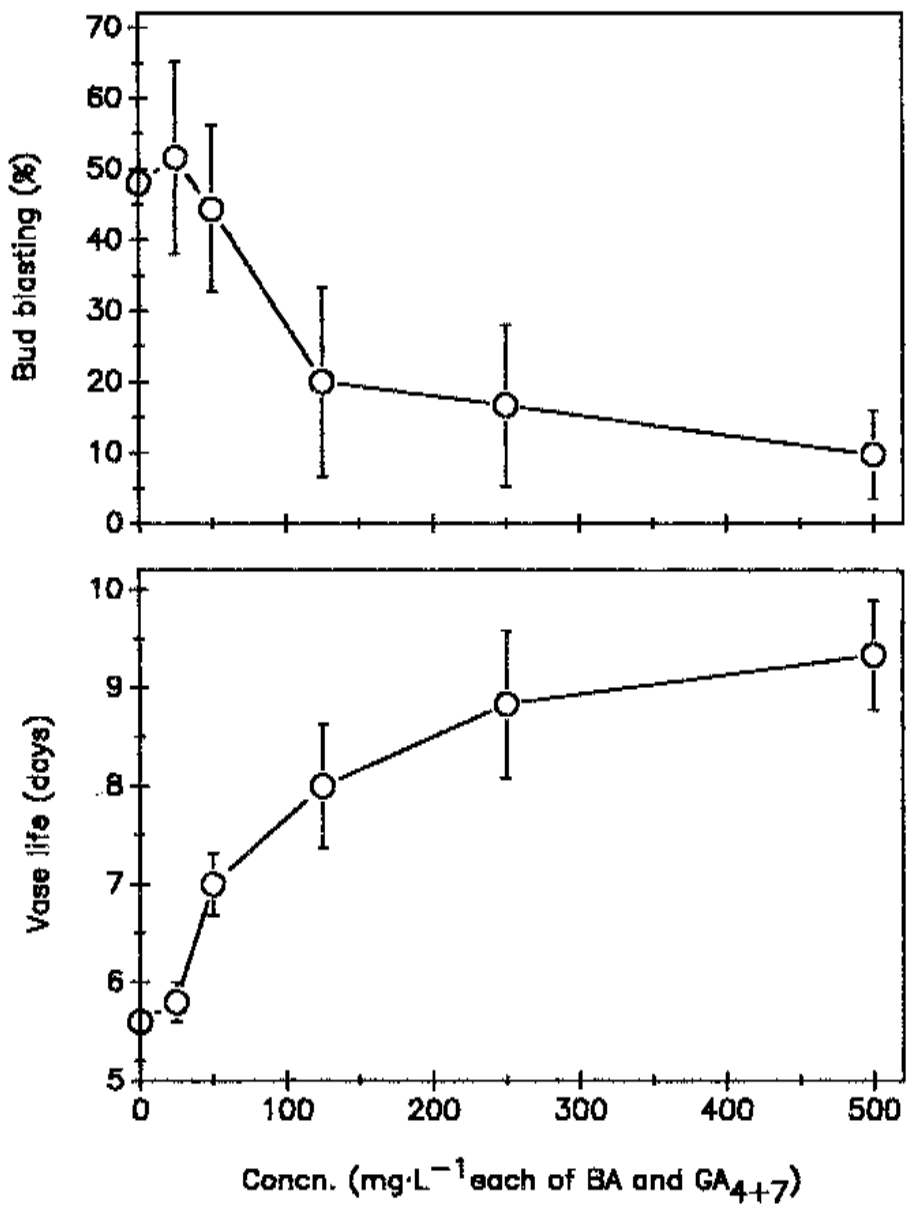

Fig. 3. Bud blasting and vase life of cut Oriental lily 'Stargazer' treated before cold storage with water (control) or various concentrations of $\mathrm{BA}$ and $\mathrm{GA}_{4+7}$. Leaves were sprayed, allowed to air dry, and then sleeved and stored in a $3{ }^{\circ} \mathrm{C}$ room for 2 weeks. Cut stems were then placed in a solution containing $2 \%$ sugar and $200 \mathrm{mg} \cdot \mathrm{L}^{-1}$ of hydroxyquinoline citrate. Data are means \pm SE of eight replicate stems.
(Hicklenton, 1991), Euphorbia fulgens Karw. ex Klotzsch (Van Leeuwen, 1986), and Chrysanthemum morifolium Ramat. (D'hont et al., 1991) was delayed by the addition of $\mathrm{GA}_{3}$ or BA to the vase solution. Bud blasting was also reported in cut chrysanthemums (D'hont et al., 1991) but not in Alstromeria hybrida and Euphorbia fulgens (Hickelton, 1991; Van Leeuwen, 1986), suggesting that the negative response of lily buds to $\mathrm{BA}+\mathrm{GA}_{4+7}$ is speciesspecific.

In addition to decreasing the quality of the leaves, cold storage at $3.3{ }^{\circ} \mathrm{C}$ significantly reduced the longevity of open flowers in both Asiatic and Oriental lilies (Table 1), induced bud blasting in Oriental lily 'Stargazer' (Table 1 ), and reduced the vase life of cut stems in all cut lilies tested. The reduced longevity of flowers can be overcome by spraying the leaves with $25 \mathrm{mg} \cdot \mathrm{L}^{-1}$ each of BA and $\mathrm{GA}_{4+7}$, although the open flowers from cold-stored, growthregulator-treated stems were inferior in quality (were smaller and often did not open fully) to those that had not been cold-stored. The coldstorage-induced bud blasting in 'Stargazer' was partly counteracted by the application of BA and $\mathrm{GA}_{4+7}$. Consequently, the vase lives of growth-regulator treated, cold-stored stems were significantly longer than that of those not treated. Concentrations of growth regulators $>50 \mathrm{mg} \cdot \mathrm{L}^{-1}$ each of $\mathrm{BA}$ and $\mathrm{GA}_{4+7}$ delayed bud opening on non-cold-stored stems but significantly reduced cold-storage-induced bud blasting, and thus increased vase life, on those cold-stored for 2 weeks. Therefore treatment with higher concentrations of growth regulators should be considered for those that will be cold-stored for an extensive period of time.

Nell et al. (1998) reported differences in cultivar responses to cold storage and noted that 'Stargazer' was prone to bud abscission, whereas flower buds of other potted lilies developed properly after cold storage. In potted 'Stargazer', storage at $1{ }^{\circ} \mathrm{C}$ for 2 weeks resulted in $100 \%$ bud abortion, whereas storage temperatures of $4{ }^{\circ} \mathrm{C}$ or higher reduced bud abortion to $\approx 30 \%$ (Ranwala and Miller, 1998). Exposure to light $\left(40 \mu \mathrm{mol} \cdot \mathrm{m}^{-2} \cdot \mathrm{s}^{-1}\right)$ or spraying leaves with a solution containing 100 $\mathrm{mg} \cdot \mathrm{L}^{-1}$ each of BA and $\mathrm{GA}_{4+7}$ nearly eliminated bud abortion. While providing sufficient light to leaves of cut lilies during cold storage might not be a viable option, since flowers are typically bundled and sleeved prior to that point, spraying leaves with a solution containing $>50 \mathrm{mg} \cdot \mathrm{L}^{-1}$ each of BA and $\mathrm{GA}_{4+7}$ could reduce bud blasting, and consequently increase vase life of the cut stems. Alternatively, breeding and selection of cultivars with better postharvest quality than 'Stargazer' might be a solution. Genetic analysis of 10 different cultivars of Asiatic lilies and their progenies suggested that postharvest quality of cut lilies can be improved by breeding (van der Meulen-Muisers et al., 1999).

In conclusion, development of leaf yellowing is a major postharvest problem in cut lilies and cold storage worsens the disorder. In addition, cold-storage induced bud blasting, prevented flowers from fully opening, and reduced longevity and size of flowers as 
well as the vase life of the cut stems. Spraying leaves with $\mathrm{BA}$ and $\mathrm{GA}_{4+7}$, before or after cold storage, significantly reduced leaf yellowing and improved the opening of flowers. Results thus provide the floricultural industry a means to minimize the deleterious effects of cold storage on leaf and flower quality of cut lilies.

\section{Literature Cited}

D'hont, K., J. Langeslag, and B.L. Dahlhaus. 1991 The effect of different growth regulators and chemical treatments used during postharvest for preserving quality of chrysanthemum. Acta Hort. 298:211-214.

Funnell, K.A. and R.D. Heins. 1998. Plant growth regulators reduce postproduction leaf yellowing of potted Asiflorum lilies. HortScience 33:10361037.

Han, S.S. 1995. Growth regulators delay foliar chlorosis of Easter lily leaves. J. Amer. Soc. Hort. Sci. 120:254-258.

Han, S.S. 1997. Preventing postproduction leaf yellowing in Easter lily. J. Amer. Soc. Hort. Sci. 122:869-872.

Hicklenton, P.R. 1991. GA 3 and benzylaminopurine delay leaf yellowing in cut Alstroemeria stems. HortScience 26:1198-1199.

Leonard, R.T., T.A. Nell, A.A. DeHertogh, and L. Gallitano. 1998. Lilies your customers will love. GrowerTalks 62:80, 82, 87-89.

Nell, T.A., R.T. Leonard, A.A. DeHertogh, and L. Gallitano. 1998. Boosting lily performance. GrowerTalks 61:62, 64, 66, 68, 70, 72.

Philosoph-Hadas, R. Michaeli, Y. Reuveni, and S. Meir. 1996. Benzyladenine pulsing retards leaf yellowing and improves quality of goldenrod (Solidago canadensis) cut flowers. Postharvest Biol. Technol. 9:65-73.

Ranwala, A.P. and W.B. Miller. 1998. Gibberel$\operatorname{lin}_{4+7}$, benzyladenine, and supplemental light improve postharvest leaf and flower quality of cold-stored 'Stargazer' hybrid lilies. J. Amer. Soc. Hort. Sci. 123:563-568.

Ranwala, A.P., W.B. Miller, T.I. Kirk, and P.A. Hammer. 2000. Ancymidol drenches, reversed greenhouse temperatures, postgreenhouse cold storage, and hormone sprays affect postharvest leaf chlorosis in Easter lily. J. Amer. Soc. Hort. Sci. 125:248-253.

SAS Institute. 1992. SAS/STAT user's guide. $4^{\text {th }}$ ed. Ver. 6. SAS Inst., Cary, N.C.

van der Meulen-Meuisers, J.J.M., J.C. van Oeveren, J. Jansen, and J.M. van Tuyl. 1999. Genetic analysis of postharvest flower longevity in Asiatic hybrid lilies. Euphytica 107:149-157. 